Selcuk Journal of Agriculture and Food Sciences

http://sjafs.selcuk.edu.tr/sjafs/index

Research Article
SJAFS

(2020) 34 (1), 19-23

e-ISSN: $2458-8377$

DOI:10.15316/SJAFS.2020.190

\title{
Determination of the Effect of Some Acidic Solutions on the Tenderness and Quality Properties of Chicken Breast Meat
}

\author{
Kübra ÜNAL ${ }^{1,}$, Eda ALAGÖZ ${ }^{1 *}$, Alime CABİ ${ }^{1}$, Cemalettin SARIÇOBAN $^{1}$ \\ ${ }^{1}$ Selçuk University, Faculty of Agriculture, Department of Food Engineering, Konya, Turkey
}

\begin{tabular}{l}
\hline ARTICLE INFO \\
\hline Article history: \\
Received date: 09.08 .2019 \\
Accepted date: 17.12 .2019 \\
\hline Edited by: \\
Ummuhan ÇETİN KARACA; Selçuk \\
University, Turkey \\
Reviewed by: \\
Hüseyin GENÇCELEP; Ondokuz Mayıs \\
University, Turkey \\
Sükrü KURT; Adıyaman University, \\
Turkey \\
\hline
\end{tabular}

Keywords:

Acetic acid

Apple cider vinegar

Tenderness

Marinating

Chicken meat

\section{Introduction}

Chicken meat is among the foods preferred by consumers in our country and worldwide with its nutritional value and reasonable price. Marination, one of the most widely used techniques to increase the flavor and tenderness of the meat, is a common technique known as a means of improving the quality of meat (Gault, 1991; Rao et al., 1989).

In acidic marination, substances such as organic acids (e.g. acetic, lactic and citric acid) and pH-lowering ingredients (e.g. soy sauce) are used as part of a flavor enhancing mixture, in contrast to sweetening additives. However, it has been reported that acidic substances have been play an important role in tenderness and flavor of processed meat (Berge et al., 2001; Gault, 1984).

In this study, it was investigated which the effect on the marination process of different concentrations of acetic acid and apple cider vinegar on the tenderness and quality characteristics of chicken breast meat.

\section{Materials and Methods}

\footnotetext{
* Corresponding author email: edaalagoz94@gmail.com
}

\subsection{Materials}

Chicken breast meats and apple cider vinegar used as materials were obtained from local market (Konya, Turkey). All the reagents and chemicals used for the research were of analytical grade and procured from Sigma Chemical Co. (St. Louis, MO).

\subsection{Sample preparation}

Chicken breast meats $(2 \times 3 \mathrm{~cm})$ were cut vertical to the muscle fibre direction from muscle samples using a knife. Solutions containing 0.1 M acetic acid (A1), 0.2 $\mathrm{M}$ acetic acid (A2), 50\% apple cider vinegar (E1), $100 \%$ apple cider vinegar (E2) were prepared in distilled water. Chicken breast meats were immersed for $48 \mathrm{~h}$ in 500 milliliters of solutions at $4^{\circ} \mathrm{C}$. Distilled water was used for the control group (C).

Moisture and fat level analysis were performed in the chicken breast meat. Cooking loss (CL), water holding capacity (WHC), marinade absorption (MA), $\mathrm{pH}$ and colour analyses were performed in the marinated chicken breast meat. Texture profile analysis was performed in marinated chicken breast meat samples cooked in the oven for 40 minutes at $250^{\circ} \mathrm{C}$ until the internal temperature reached $72^{\circ} \mathrm{C}$.

\section{3. pH measurement}


$\mathrm{pH}$ values of the samples were measured by penetrate with a $\mathrm{pH}$ meter (Testo $205 \mathrm{~T}$-Handle $\mathrm{pH} \mathrm{Me}$ ter/Thermometer w/ Penetration Tip) before marination and after marination (Lambooij et al., 1999).

\subsection{Proximate analyses}

Moisture (hot air oven) and fat (ether extraction) contents of the samples were determined using standard methods of AOAC (2000).

\subsection{Determination of cooking loss $(C L)$}

The method described by Young and Buhr (2000) was used to determine weight loss of chicken breast meat after cooking. Approximately 8-10 grams of sample was put into polyethylene bags and cooked in a water bath for 30 minutes at an internal temperature of $75^{\circ} \mathrm{C}$. The separated water was removed from the samples and the loss of cooking was calculated by weighing the samples.

\subsection{Determination of water holding capacity (WHC)}

Centrifugation method was used to determine the WHC of the samples. $2 \mathrm{~g}$ homogenized chicken breast meat samples were weighted on filter paper and placed in centrifuge tubes. After centrifugation at $2000 \mathrm{rpm}$ for 10 minutes, the wet filter paper was weighted (W1). The filter paper was then dried in the oven at $60^{\circ} \mathrm{C}$ until constant weight and then reweighted (W2). The WHC of chicken breast meats was calculated as the amount of sample remaining after centrifugation (Gómez-Guillén et al., 2000).

\subsection{Determination of marinade absorption (MA)}

The MA of the marinated samples was determined on a weight basis before marination process and after the marination process, according to the method given by Young and Buhr (2000).

\subsection{Color properties of chicken breast meats}

The surface colour of the cooked marinated chicken breast meats was evaluated using a chroma meter CR40 (Konica Minolta, Inc., Osaka, Japan) with illuminant D65, $2^{\circ}$ observer, Diffuse/O mode, $8 \mathrm{~mm}$ aperture of the instrument for illumination and $8 \mathrm{~mm}$ for measurement, calibrated against a white tile. Colour measurements (CIE $L^{*}, a^{*}$ and $b^{*}$ values representing lightness, redness and yellowness, respectively) were taken marinated uncooked samples and marinated cooked samples. For colour measurement, cooked samples were cooled to room temperature. $L^{*}$ (lightness), $a^{*}$ (redness, +60 , red; -60 , green) and $b^{*}$ (yellowness, +60 , yellow; -60 , blue) color coordinates according to the CIE $L^{*} a^{*} b^{*}$ color coordinate system (CIE, 1976). The measurement was made by directly upon three different parts of the samples placed on a white background.

\subsection{Texture measurement}

TPA parameters (hardness $(\mathrm{N})$, cohesiveness, chewiness $(\mathrm{Nxmm})$, gumminess $(\mathrm{N})$ and adhesiveness (g.sec)) of the marinated cooked chicken breast meat samples were performed using a Texture Analyzer (TA.HD Plus Texture Analyser, UK) at room temperature and following specifications were applied: $50 \mathrm{~N}$ load cell, $1 \mathrm{~mm} / \mathrm{min}$ speed before the test, $5 \mathrm{~mm} / \mathrm{min}$ speed during and after the test, cylindrical probe with $36 \mathrm{~mm}$ diameter (Modi et al., 2009).

For MORS analysis, Meullenet-Owens Razor Shear probe connected to TA.HD Plus texture analyzer was used. Blade penetration depth was set at $20 \mathrm{~mm}$ (Sawyer et al., 2007). Analysis probe was dipped into 3 different regions of each chicken breast meat. $50 \mathrm{~N}$ load cell, $2 \mathrm{~mm} / \mathrm{min}$ speed before the test, $10 \mathrm{~mm} / \mathrm{min}$ speed during and after the test was set.

\subsection{Statistical analysis}

The data obtained as a result of the analyzes were subjected to variance analysis using MINITAB release 16.0 program as tables prepared in accordance with the experimental design. Tukey test was used for comparison of means, with significance assigned at $p<0.05$ and $p<0.01$. Each parameter was tested in triplicate samples with two replications.

\section{Results and Discussion}

According to result of research, it was found that the moisture and fat content of unmarinated chicken breast meat was $74.6 \%$ and $3.6 \%$, respectively. The $\mathrm{pH}$ values of unmarinated chicken meat, $0.1 \mathrm{M}$ and $0.2 \mathrm{M}$ acetic acid solution, 50\% apple cider vinegar and $100 \%$ apple cider vinegar were determined as 6.11, 3.03, 2.86 and 2.97 and 2.89 respectively.

The $\mathrm{pH}$ values of chicken breasts treated with different concentrations of acetic acid solution and apple cider vinegar are given in Table 1 . The $\mathrm{pH}$ of the samples decreased significantly with the addition of acetic acid and apple cider vinegar $(p<0.01) . \mathrm{pH}$ is an important criterion for changes in foods treated with acidic marinades. It is thought that the difference between the $\mathrm{pH}$ values of the marinated chicken breasts is due to the different $\mathrm{pH}$ values of the marinades used. It is shown that the $\mathrm{pH}$ values of chicken breast meat decreased in parallel with the marinad $\mathrm{pH}$ values in Table 1. The highest $\mathrm{pH}$ value (5.66) belongs to the control group, while the lowest $\mathrm{pH}$ value (3.53) was observed in the E2 group. Aktaş et al. (2003) were also obtain similar results in their study with organic acids. In a study in which chicken breast meats were marinated with apple cider vinegar, pomegranate juice and lemon juice at different temperatures and times, it has been reported which the $\mathrm{pH}$ values of chicken breast meats treated with lemon juice were lower than the others, on the other hand those with marinated pomegranate juice had the highest $\mathrm{pH}$ value (Lytou et al., 2017). In study carried out by Serdaroglu et al. (2007) also reported that the highest and lowest $\mathrm{pH}$ values of turkey meat marinated using citric acid solution and grapefruit juice belonged to the control group and the group treated with $0.2 \mathrm{M}$ citric acid solution, respectively. 
Table 1

$\mathrm{pH}$, water holding capacity (WHC), cooking loss (CL) and marinade absorption (MA) values of chicken breast meats treated with different concentrations of acetic acid and apple vinegar.

\begin{tabular}{lcccc}
\hline Treatment & $\mathrm{pH}$ & WHC $(\%)$ & $\mathrm{CL}(\%)$ & $\mathrm{MA}(\%)$ \\
\hline Control & $5.66 \pm 0.04^{\mathrm{a}}$ & $20.69 \pm 3.10^{\mathrm{a}}$ & $37.81 \pm 0.92^{\mathrm{a}}$ & $4.40 \pm 0.57^{\mathrm{c}}$ \\
A1 & $4.93 \pm 0.37^{\mathrm{ab}}$ & $27.35 \pm 4.03^{\mathrm{a}}$ & $22.44 \pm 4.04^{\mathrm{bc}}$ & $5.01 \pm 0.01^{\mathrm{c}}$ \\
A2 & $4.14 \pm 0.28^{\mathrm{bc}}$ & $28.67 \pm 5.89^{\mathrm{a}}$ & $25.72 \pm 0.21^{\mathrm{b}}$ & $20.69 \pm 0.98^{\mathrm{b}}$ \\
E1 & $4.32 \pm 0.26^{\mathrm{bc}}$ & $15.14 \pm 0.40^{\mathrm{a}}$ & $20.24 \pm 2.74^{\mathrm{bc}}$ & $22.88 \pm 1.25^{\mathrm{b}}$ \\
E2 & $3.53 \pm 0.03^{\mathrm{c}}$ & $18.70 \pm 4.52^{\mathrm{a}}$ & $15.19 \pm 0.26^{\mathrm{c}}$ & $41.06 \pm 1.50^{\mathrm{a}}$ \\
\hline
\end{tabular}

${ }^{\mathrm{a}-\mathrm{c}}$ Means within a column with different letters are significantly different. $(p<0.01)$. Means based on six values. $(\mathrm{n}=6)$

Control: Distilled water; A1: 0.1 M acetic acid; A2: 0.2 M acetic acid; E1: 50\% apple cider vinegar; E2: 100\% apple cider vinegar.

The WHC of meat is very important because many physical properties such as color and texture are partly dependent on WHC (Ketnawa and Rawdkuen, 2011). Table 1 shows the WHC of chicken breasts treated with acetic acid solution and apple cider vinegar. Chicken breast meats treated with $0.1 \mathrm{M}$ and $0.2 \mathrm{M}$ acetic acid have the highest WHC $(27.34 \%, 28.66 \%)$. At the same time, samples containing apple cider vinegar showed lower WHC than the control group. WHC increased in parallel with acetic acid and apple vinegar concentration. However, the difference between them is statistically insignificant $(p>0.05)$. It is thought that this difference between treatments may be due to the fact that the marinade solutions have different acetic acid ratios. It has been reported in several studies that low $\mathrm{pH}$ has a strong effect on proteins, that the effect of acids on tissue can be depends on the type of fiber in the meat, whereas high $\mathrm{pH}$ promotes the swelling of collagen surrounding the muscle fibers (Aktaş et al., 2003; Rao and Gault, 1989; Rao et al., 1989).

The CL (\%) values of all samples are shown in Table 1 . CL values of the samples treated with acid solution and apple cider vinegar were lower than the control group $(p<0.01)$. While the cooking loss of chicken breast meats treated with acetic acid solution increased with increasing concentration, CL of apple cider vinegar decreased with increasing concentration. The least CL (15.19\%) occurred in chicken breast meat treated with $100 \%$ apple cider vinegar. At the point where the positive and negative charges of chicken breast meat proteins are equal $(\mathrm{pH}=6.00)$, they cause the amount of water bound to the proteins to decrease due to the pulling of these loads. As the $\mathrm{pH}$ value moves away from this point, the less water is removed from the structure. Therefore, it is thought that the loss of cooking decrease with increasing acidity value. In the study of Aktaş et al. (2003) that they marinated beef with $0.5,1,1.5 \%$ lactic acid and citric acid solution, the lowest CL in beef was obtained in marinated samples at the highest lactic and citric acid concentrations. They reported that this might occur from the effect of acidic $\mathrm{pH}$ on proteins.

MA varies depending on the selected region of poultry meat. It has been stated that chicken breast meats absorb marinade more than thigh meats (Arganosa and Marriott, 1989). The MA values of all treatment groups are shown in Table 1. The group with the highest value was group applied $100 \%$ apple cider vinegar $(41.06 \%)$ while the lowest value belong to the control group $(4.40 \%)$. The difference between the treatments in terms of MA was statistically significant $(p<0.01)$. However, it was found that the MA values of the treatment groups increased proportionally with decrease in $\mathrm{pH}$. This situation is thought to be related to the isoelectric point of the proteins in the structure of chicken breast meat as in the loss of cooking values. It is thought that in parallel with these data, in another study investigating the sensory and some technological properties of marinated poultry meats by using different ratios of citric acid, it has been reported that MA was increased final weight of all treatment groups as the function of $\mathrm{pH}$ effect and the highest value was obtained at pH 4.00 (Yusop et al., 2010).

The color parameters of each treatment group were determined as raw and cooked and all values are given in Table 2. According to the results of the study, $L^{*}$, $a^{*}, b^{*}$ values of all groups showed statistically significant changes. Among the marinated raw samples, the highest $L^{*}$ and $a^{*}$ values were determined in the control group and the highest $b^{*}$ values were determined in the E1 group while the lowest $L^{*}$ and $a^{*}$ values were found in E2 and the lowest $b^{*}$ values were found in A2 group. Among the cooked groups, the highest $L^{*}$ value belongs to the control group and the highest $a^{*}$ and $b^{*}$ values belong to the A1 group, while the lowest $L^{*}$ and $b^{*}$ values was determined in the E2 group and the lowest $a^{*}$ value was determined in the A2 group. Although $\mathrm{pH}$ change did not have a significant effect on color, it was concluded that color parameters decreased due to increase in concentration between treatments. In a study, it was reported that $a^{*}$ values did not differ in turkey meat samples treated with citric acid and grape juice (Serdaroğlu et al., 2007). Nadzirah et al. (2006) indicated that the brightness values of the marinated samples increased and $a^{*}$ value decreased. In another study, it was reported that the $L^{*}$ value of marinated chicken breast meats decreased (Smith and Young, 2007). Northcutt et al. (2000) reported that there was statistically no difference between the brightness values of marinated and unmarinated raw and heat treated chicken fillets. In general, it is thought that the color of the acidic fruit or organic acid used may change the color characteristics of the meat treated with it. 
Table 2

$L^{*}, a^{*}$ and $b^{*}$ values of raw and cooked chicken breast meats treated with different concentrations of acetic acid and apple cider vinegar.

\begin{tabular}{lcccc}
\hline & Treatment & $L^{*}$ & $a^{*}$ & $b^{*}$ \\
\hline \multirow{4}{*}{ Raw } & Control & $62.48 \pm 0.03^{\mathrm{a}}$ & $0.84 \pm 1.25^{\mathrm{a}}$ & $7.20 \pm 0.69^{\mathrm{a}}$ \\
& A1 & $61.80 \pm 0.31^{\mathrm{ab}}$ & $0.16 \pm 1.35^{\mathrm{a}}$ & $8.36 \pm 0.17^{\mathrm{a}}$ \\
& A2 & $57.09 \pm 2.32^{\mathrm{bc}}$ & $-0.32 \pm 0.63^{\mathrm{a}}$ & $3.25 \pm 0.07^{\mathrm{b}}$ \\
\hline & E1 & $62.16 \pm 1.61^{\mathrm{ab}}$ & $-1.02 \pm 0.13^{\mathrm{a}}$ & $9.31 \pm 0.34^{\mathrm{a}}$ \\
E2 & Eontrol & $74.61 \pm 0.71^{\mathrm{c}}$ & $-1.06 \pm 0.05^{\mathrm{a}}$ & $4.00 \pm 1.20^{\mathrm{b}}$ \\
\hline & A1 & $76.76 \pm 0.55^{\mathrm{a}}$ & $1.65 \pm 1.34^{\mathrm{a}}$ & $18.53 \pm 1.18^{\mathrm{b}}$ \\
& A2 & $67.17 \pm 1.74^{\mathrm{b}}$ & $1.72 \pm 0.19^{\mathrm{a}}$ & $23.31 \pm 0.90^{\mathrm{a}}$ \\
& E1 & $72.41 \pm 1.98^{\mathrm{ab}}$ & $0.27 \pm 1.99^{\mathrm{a}}$ & $18.18 \pm 0.88^{\mathrm{b}}$ \\
& E2 & $72.75 \pm 1.88^{\mathrm{ab}}$ & $0.74 \pm 0.00^{\mathrm{a}}$ & $17.07 \pm 0.06^{\mathrm{b}}$ \\
\hline
\end{tabular}

${ }^{\mathrm{a}-\mathrm{c}}$ Means within a column with different letters are significantly different. $(p<0.01)$. Means based on six values. $(\mathrm{n}=6)$

Control: Distilled water; A1: 0.1 M acetic acid; A2: 0.2 M acetic acid; E1: 50\% apple cider vinegar; E2: 100\% apple cider vinegar.

The results of the texture profile analysis of the samples marinated with acetic acid and apple cider vinegar are given in Table 3. According to the results of the analysis, there was a significant difference between the values of shear strength (MORS) $(p<0.05)$. It has found that the highest hardness value was group including $0.1 \mathrm{M}$ acetic acid with $134.1 \mathrm{~N}$ while the lowest hardness was group including $100 \%$ apple cider vinegar with $60.28 \mathrm{~N}$. Both concentrations of apple cider vinegar and $0.2 \mathrm{M}$ acetic acid reduced the hardness of chicken breasts significantly compared to the control group. The shear force of all treatment groups was between 9.7-5.1 $\mathrm{N}$ and the highest and lowest values were found to be the control and E2 groups, respectively. In terms of shear force, the difference between chicken breast meat marinated with $100 \%$ apple cider vinegar and other groups was statistically significant $(p<0.01)$. The cohesiveness values of chicken meat samples varied between 0.26 and 0.32 . In terms of these values, the difference between treat- ments was not statistically significant, and acetic acid solution treated groups were increased more than compared to control group. It is reported that the mechanism of the tenderising action of acidic marinades is affect to several factor including increased proteolysis by cathepsins, weakening of structures, and increased conversion of collagen to gelatin at low $\mathrm{pH}$ during cooking. It has been reported that when the $\mathrm{pH}$ drops below the isoelectric point, the hardness increases and the acidic marinades used are responsible for increasing the hardness of chicken breast meats (Önenç et al., 2004; Sheard and Tali, 2004). In a study in which marinated turkey meat using mixed vegetable and fruit juices, it was reported that the lowest hardness value was found in pomegranate and red grape juice and the hardness values increased with cooking process (Gök and Bor, 2016). Goli et al. (2014) have reported that $0.25 \mathrm{M}$ aqueous acetic acid solution was decreased hardness and shear force of turkey breast meat over time, but it was increased slightly in presence of salt.

Table 3

Texture profile analysis results of chicken breast meats treated with different concentrations of acetic acid and apple cider vinegar.

\begin{tabular}{|c|c|c|c|c|c|c|}
\hline Treatment & $\begin{array}{l}\text { Hardness } \\
(\mathrm{N})\end{array}$ & $\begin{array}{c}\text { Gumminess } \\
(\mathrm{N})\end{array}$ & Cohesiveness & $\begin{array}{l}\text { Chewiness } \\
\text { (Nxmm) }\end{array}$ & $\begin{array}{l}\text { Adhesiveness } \\
\text { (gxs) }\end{array}$ & Shear Force $(\mathrm{N})$ \\
\hline Control & $123.31 \pm 17.08^{\mathrm{a}}$ & $33.35 \pm 8.46^{\mathrm{a}}$ & $0.27 \pm 0.03^{\mathrm{a}}$ & $18.61 \pm 5.23^{\mathrm{a}}$ & $-3.34 \pm 2.18^{\mathrm{a}}$ & $9.70 \pm 0.61^{\mathrm{a}}$ \\
\hline $\mathrm{A} 1$ & $134.18 \pm 2.16^{\mathrm{a}}$ & $42.97 \pm 6.51^{\mathrm{a}}$ & $0.32 \pm 0.04^{\mathrm{a}}$ & $25.90 \pm 4.60^{\mathrm{a}}$ & $-7.25 \pm 1.78^{\mathrm{a}}$ & $9.33 \pm 0.77^{\mathrm{a}}$ \\
\hline $\mathrm{A} 2$ & $124.92 \pm 47.59^{\mathrm{a}}$ & $40.66 \pm 17.16^{\mathrm{a}}$ & $0.32 \pm 0.01^{\mathrm{a}}$ & $20.96 \pm 7.17^{\mathrm{a}}$ & $-8.60 \pm 9.69^{a}$ & $8.67 \pm 0.39^{a}$ \\
\hline E1 & $76.16 \pm 6.82^{\mathrm{a}}$ & $21.18 \pm 3.54^{\mathrm{a}}$ & $0.28 \pm 0.02^{\mathrm{a}}$ & $11.33 \pm 2.60^{\mathrm{a}}$ & $-2.49 \pm 0.07^{\mathrm{a}}$ & $8.67 \pm 1.01^{\mathrm{a}}$ \\
\hline E2 & $60.28 \pm 8.40^{\mathrm{a}}$ & $17.47 \pm 2.05^{\mathrm{a}}$ & $0.29 \pm 0.01^{\mathrm{a}}$ & $8.72 \pm 0.61^{\mathrm{a}}$ & $-16.83 \pm 7.50^{\mathrm{a}}$ & $5.11 \pm 0.35^{\mathrm{b}}$ \\
\hline
\end{tabular}

In this study, quality and textural properties of chicken breast meats marinated with different concentration of acetic acid solution $(0.1 \mathrm{M}$ and $0.2 \mathrm{M})$ and apple cider vinegar $(50 \%$ and $100 \%)$ for 48 hours were investigated. Thus, it was investigated whether apple cider vinegar can be used as a natural alternative to an organic acid solution in marinating chicken meat. It was determined that chicken breast meat samples treated with acetic acid and apple cider vinegar have much more acceptable structure and hardness values decreased. It was observed that the lowest hardness value was belong to chicken breast meats treated with $100 \%$ apple vinegar. When the results of the analysis are view, it was seen that the apple cider vinegar solution improved in a positive way the quality and textural properties of chicken breast meats. It is concluded that apple cider vinegar is more effective on the textural properties of chicken breast meat than acetic acid which is an organic acid in the natural structure of vinegar. Therefore, it can be suggested that apple cider vinegar may be a natural alternative source for use as a marination solution. 


\section{References}

Aktaş N, Aksu MI, Kaya M (2003). The effect of organic acid marination on tenderness, cooking loss and bound water content of beef. Journal of Muscle Foods 14(3): 181-194.

AOAC (2000). Official Methods of Analysis of AOAC International, 17th ed. P. Cunniff. AOAC Int., Arlington, Virginia, USA.

Arganosa GC, Marriott NG (1989). Organic acids as tenderizers of collagen in restructured beef. Journal of Food Science 54(5): 1173-1176.

Berge P, Ertbjerg P, Larsen LM, Astruc T, Vignon X, Møller AJ (2001). Tenderization of beef by lactic acid injected at different times post mortem. Meat Science 57(4): 347-357.

CIE (1976). International Commission on Illumination, Colorimetry: official recommendations of the International Commission on Illumination. Publication CIE, No: 15 (E-1.3.1), Paris, France: Bureau Central de la CIE.

Gault NFS (1984). The influence of acetic acid concentration on the efficiency of marinading as a process for tenderizing beef. In Proceedings of the 30th European Meeting of Meat Research Workers, pp. 184-185.

Gault NFS (1991). Marinaded meat. Developments in Meat Science 5:191-246.

Goli T, Ricci J, Bohuon P, Marchesseau S, Collignan A (2014). Influence of sodium chloride and $\mathrm{pH}$ during acidic marination on water retention and mechanical properties of turkey breast meat. Meat Science 96(3): 1133-1140.

Gómez-Guillén MC, Montero P, Hurtado O, Borderías AJ (2000). Biological characteristics affect the quality of farmed Atlantic salmon and smoked muscle. Journal of Food Science 65(1): 53-60.

Gök V, Bor Y (2016). Effect of marination with fruit and vegetable juice on the some quality characteristics of turkey breast meat. Brazilian Journal of Poultry Science 18(3): 481-488.

Ketnawa S, Rawdkuen S (2011). Application of bromelain extract for muscle foods tenderization. Food and Nutrition Sciences 2(05): 393.

Lambooij E, Potgieter CM, Britz CM, Nortje GL, Pieterse C (1999). Effects of electrical and mechanical stunning methods on meat quality in ostriches. Meat Science 52(3): 331-337.

Lytou AE, Panagou EZ, Nychas GJE (2017). Effect of different marinating conditions on the evolution of spoilage microbiota and metabolomic profile of chicken breast fillets. Food Microbiology 66: 141149.

Modi VK, Yashoda KP, Naveen SK (2009). Effect of carrageenan and oat flour on quality characteristics of meat kofta. International Journal of Food Properties 12(1): 228-242.
Nadzirah KZ, Zainal S, Noriham A, Normah I (2016). Application of bromelain powder produced from pineapple crowns in tenderising beef round cuts. International Food Research Journal, 23(4): 15901599.

Northcutt JK, Smith DP, Buhr RJ (2000). Effects of bruising and marination on broiler breast fillet surface appearance and cook yield. Journal of Applied Poultry Research 9(1): 21-28.

Önenç A, Serdaroğlu M, Abdraimov K (2004). Effect of various additives to marinating baths on some properties of cattle meat. European Food Research and Technology 218(2): 114-117.

Rao MV and Gault N. (1989). The influence of fibretype composition and associated biochemical characteristics on the acid buffering capacities of several beef muscles. Meat Sci. 26: 5-18.

Rao MV, Gault NFS, Kennedy S (1989). Changes in the ultrastructure of beef muscle as influenced by acidic conditions below the ultimate pH. Food Structure 8: 115-124.

Rao MV, Gault NFS, Kennedy S (1989). Variations in water holding capacity due to changes in the fibre diameter, sarcomere length and connective tissue morphology of some beef muscles under acidic conditions below the ultimate pH. Meat Sci. 26: 19 37.

Sawyer JT, Baublits RT, Apple JK, Meullenet JF, Johnson ZB, Alpers TK (2007). Lateral and longitudinal characterization of color stability, instrumental tenderness, and sensory characteristics in the beef semimembranosus. Meat Science 75(4): 575-584.

Serdaroğlu M, Abdraimov K, Oenenc A (2007). The effects of marinating with citric acid solutions and grapefruit juice on cooking and eating quality of turkey breast. Journal of Muscle Foods 18(2): 162172.

Sheard PR, Tali A (2004). Injection of salt, tripolyphosphate and bicarbonate marinade solutions to improve the yield and tenderness of cooked pork loin. Meat Science 68(2): 305-311.

Smith DP, Young LL (2007). Marination pressure and phosphate effects on broiler breast fillet yield, tenderness, and color. Poultry Science 86(12): 26662670.

Young LL, Buhr RJ (2000). Effect of electrical stimulation and polyphosphate marination on drip from early-harvested, individually quick-frozen chicken breast fillets. Poultry Science 79(6): 925-927.

Yusop SM, O’Sullivan MG, Kerry JF, Kerry JP (2010). Effect of marinating time and low $\mathrm{pH}$ on marinade performance and sensory acceptability of poultry meat. Meat Science 85(4): 657-663. 